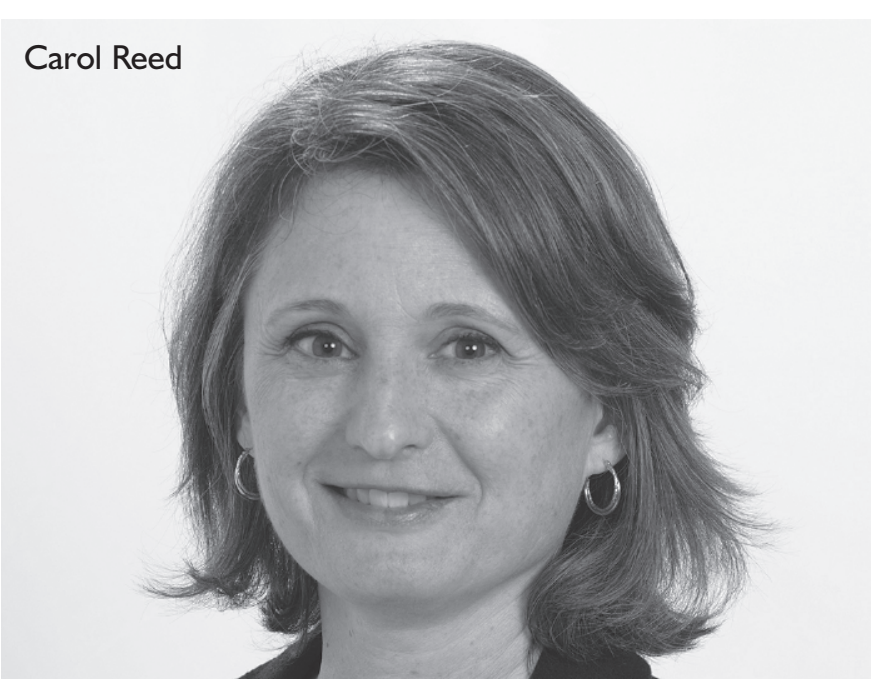

be more efficient for the author to make changes, it's OK to say so. Occasionally an author gets trapped in an endless cycle of tweaks and un-tweaks in which the indexer is nothing more than a highly paid typist; that's not a great use of the author's budget or the indexer's time. Or an author is obviously rewriting the book during and after indexing.
You might respectfully point out that the value the author is trying to add to the index has more to do with their subject expertise and their understanding of the audience's needs than with your indexing skills.

Many difficult situations with authors can be prevented with some intentional communication at the outset. Like so many projects, it's easy to skimp on preparation tasks when you are impatient to get started on the visible work. Cutting corners early on can create disasters later. Improving your communication with authors doesn't actually take that much time, and you'll be rewarded with better working relationships, more referrals, and better indexes.

\section{Acknowledgement}

This article was original published in the Fall 2014 Newsletter of the ASI Heartland Chapter, by whose kind permission it is reprinted here.

Carol Reed is a freelance indexer and technical writer. She is co-president and newsletter editor of the ASI Heartland Chapter, and is also active in the Society for Technical Communication.

Email: caree15abluestemclarity.com

\title{
Indexes in award-winning cookbooks
}

\section{Catherine Sassen}

The author considers whether the quality of a cookbook is reflected in the quality of its index.

\section{Introduction}

Award-winning cookbooks are publicized through press releases, presentation ceremonies, websites, and booksellers. Although it is easy to find information about these cookbooks, it is difficult to find any assessment of their indexes. If a cookbook wins an award for excellence, can we assume that it includes a good index?

Reviewers have indicated that a good index contributes to the value of a cookbook. For example, Al Sicherman (1998) noted that 'an extremely user-friendly index' is an important feature of How to cook everything. Furthermore, a poor index will detract from the worth of a cookbook. For example, Lucy Waverman (2008) criticized the 'sloppy, inadequate index' in Anita Stewart's Canada. Reviewers have also complained that a cookbook is deficient if it lacks an index. For example, James Means (2009) remarked that Kitchen express is 'pretty much useless' because it does not include an index. Perhaps Julia Child (2005: vii) should have the last word on this issue, as she wrote, 'A reference or teaching book is only as good as its index.'

\section{Literature review}

Few researchers have compared and evaluated cookbook indexes. Hall (2009) analyzed the 'impeccable indexes' in five cookbooks. She identified their most outstanding features as 'readability (in terms of white space and column width), ample cross-references, a legible font and color, and a minimum size of 3 percent of the page count allocated to the index' (Hall, 2009: 63). Sassen (2003) examined the indexes in the 13 major editions of The Boston CookingSchool cook book and its successor, The Fannie Farmer cook book, from 1896 to 1996. She analyzed each index with criteria from culinary indexing experts and discussed how the indexes had changed over time. Indexes published from 1965 to 1996 included more access to main ingredients, more succinct headings for recipe categories and more cross-references. Sassen (2009) used the same approach in her analysis of the indexes in eight editions of The joy of cooking published from 1931 to 2006. She found that the more recent indexes provided greater access to recipe titles and illustrations. Recent indexes were easier to navigate because of the increased use of cross-references.

\section{Methodology}

The purpose of this study was to analyze indexes in award-winning cookbooks, using criteria defined by culinary indexing experts. The researcher focused on cookbooks that had won awards from British, American, and international organizations from 2010 through 2014. The awards include the Guild of Food Writers Cookery Book of the Year Award, the James Beard Foundation Cookbook of the Year Award, 
and the International Association of Culinary Professionals Cookbook of the Year Award.

The Guild of Food Writers (2015a) is a professional association for British food authors and journalists. The Guild began making awards in 1996 to recognize 'outstanding achievements in food writing and broadcasting' (Guild of Food Writers, 2015b).

The James Beard Foundation (2015) focuses on the culinary heritage of America. The Foundation began presenting awards in 1991 to recognize 'excellence in the food and beverage and related industries.'

The International Association of Culinary Professionals (2015a) is composed of culinary specialists from more than 32 countries. The Association began giving awards in 1986 'to promote quality and creativity in writing and publishing, and to expand the public's awareness of culinary literature' (International Association of Culinary Professionals, 2015b).

The cookbooks used in this study are listed in the Appendix to this article. Many of these cookbooks are composed primarily of recipes and related illustrations. A few of the cookbooks also include lengthy essays with accompanying photographs. For example, Stone Edge Farm cookbook (McReynolds, 2013) consists of 371 pages, including 102 'primary recipes,' 300 illustrations, and essays on gardening, winemaking, and vineyards. Tasting India (Manfield, 2011) is comprised of 477 pages, including over 250 recipes. It also includes essays and photographs about the regions and food customs of India. Historic Heston (Blumenthal, 2013) is a two-volume set with extensive information about British culinary history from medieval to Victorian times. Modernist cuisine: the art and science of cooking (Myhrvold, 2011) is the most unusual cookbook in the study. This work consists of 2,438 pages in six lavishly illustrated volumes emphasizing food science and technology.

This study includes two editions of the same cookbook. The British and US editions of Jerusalem by Ottolenghi and Tamimi (2012) are included in the study because both were mentioned in awards announcements. The Guild of Food Writers named the British edition as the winner of its 2013 Cookery Book of the Year award. The International Association of Culinary Professionals cited both the British and US editions in its 2013 Cookbook of the Year award announcement. The indexes of these two editions are very similar. The most noticeable difference is that 'aubergine' appears in the index of the British edition, while its synonym 'eggplant' appears in the index of the US edition.

\section{Limitations}

I attempted to locate the appropriate edition of each cookbook through local libraries and interlibrary loan, and was successful in finding all but one. The exception was Tasting India (Manfield, 2011), which won the 2012 Cookbook of the Year award from the International Association of Culinary Professionals. I was not able to find the version published by Penguin in Australia, and examined the version published by Conran Octopus in Great Britain instead.

Another limitation concerns the constraints faced by the culinary indexers whose indexes were examined in this study. No information is available about index length restrictions, time constraints, instructions from editors, or any other conditions affecting the creation of these indexes. Some of the index features mentioned in this study may have been beyond the control of the indexer.

\section{Results}

\section{Index inclusion}

Of the 15 cookbooks, 14 include indexes. The exception was Oaxaca al gusto: an infinite gastronomy (Kennedy, 2010), which won the 2011 James Beard Cookbook of the Year award. This is a substantial volume of 458 pages, published by the University of Texas Press. The section of the book labeled 'index' is simply an expanded table of contents, listing all recipe titles in the order in which they appear in each chapter of the book. The process of searching this list for recipes is difficult. For example, a reader looking for salsa recipes will find them scattered throughout the list under 12 different chapter titles. Alma Guillermopreto (2011) reviewed this cookbook for the New York Review of Books, and wrote that she found the lack of an alphabetical index to be inexplicable.

ISO 999 (International Organization for Standardization, 1996: 2) defines an index as an 'alphabetically or otherwise ordered arrangement of entries, different from the order of the document or collection indexed, designed to enable users to locate information in a document or specified documents in a collection.' Because the recipe list in Oaxaca al gusto did not fit the definition of an index, it was excluded from further analysis in this study. The remaining 14 cookbooks included proper indexes that were examined in depth.

\section{Main ingredients}

Recipes should be indexed under main ingredients (Bertelsen, 1999: 6; Wellisch, 1995: 96). Shere (2009: 24) defined these ingredients as 'key to the recipe, making the dish what it is, or so distinctive, though minor, that a reader might look them up to see what may be done with them.' All 14 indexes include entries for main ingredients.

\section{Types of dish}

Recipes should be indexed under types of dish or recipe categories, such as 'beverages,' 'cakes' and 'salads' (Bertelsen, 1999: 6; Wellisch, 1995: 95). All 14 indexes provide this type of access to recipes.

\section{Recipe titles}

A recipe should be indexed under its title, with some exceptions (Shere, 2009). The exceptions to this guideline vary from one indexing expert to another. Wellisch (1995: 95) and Watts (2014: C2) advised against indexing a recipe title under initial adjectives describing a cooking method such as 'baked' or 'grilled.' Wellisch (1995: 95) also argued against indexing a recipe under initial modifiers that are 'nondistinctive,' such as 'homestyle' or 'quick.' However, Watts (2014: C3-4) recommended the indexing of titles beginning 
with 'attractive or evocative terms' such as 'easy,' 'decadent' and 'quick' because 'those types of recipes are often exactly what the reader is looking for.'

Wellisch (1995: 96) also advised against including the name of a person in a heading for a recipe title 'unless such a name has become an integral part of the name by which a dish is known' such as 'Sacher torte.' However, Weinberg (1999: 9) noted, 'If you recall the name of an eponymic recipe, an index entry for its title is a far faster way to access the recipe than the common terms for the ingredients.'

All 14 indexes in this research study include main headings for recipe titles.

\section{Illustrations}

Wellisch (1995: 96) wrote that illustrations of dishes and preparation methods should be indexed. However, this may not be possible if the illustrations were not included in the text provided to the indexer. Illustrations were indexed in seven cookbooks in this study. In two of these cookbooks, illustrations were indexed only if they appeared adjacent to the recipes they illustrated.

\section{Cross-references}

Indexes should include see references to refer readers to preferred terms, as well as see also references to refer readers to related terms (Whitman and Simon, 2000: 143). Of the 14 indexes, 13 include cross-references. The exception is the recipe index of Ice creams, sorbets \& gelati: the definitive guide (Weir and Weir, 2010).

\section{Non-English terminology}

Including foreign language terms and their English language translations in the index may be helpful to the cookbook user (Bertelsen, 2009: 38-9). The indexes in this study vary in the ways that they handle non-English language terms.

Nine of the indexes include entries for foreign language terms followed by English language translations. These indexes also include separate postings for the terms translated into English. For example, in the indexes of both the British and US editions of Jerusalem (Ottolenghi and Tamimi, 2012), there are entries for 'a'ja (bread fritters)' and 'bread fritters (a'ja)'.

The index for Warm bread and honey cake (PagrachChandra, 2009) includes various foreign language terms and their English language translations, but these terms do not appear next to each other in the index. For example, the recipe entitled 'Walnut roll/Potica' is indexed as 'walnut roll' and 'potica.'

The remaining four indexes provide less access to English language translations of foreign language terms. The index for Couture chocolate (Curley, 2011) includes foreign language terms followed by English language translations, but the English language translations are not posted separately. The index to Gran cocina Latina (Presilla, 2012) includes Spanish language terms, but many of them are not followed by English language translations that are also posted separately. Finally, the indexes of Modernist cuisine (Myhrvold, 2011) and Ice creams, sorbets \& gelati (Weir and

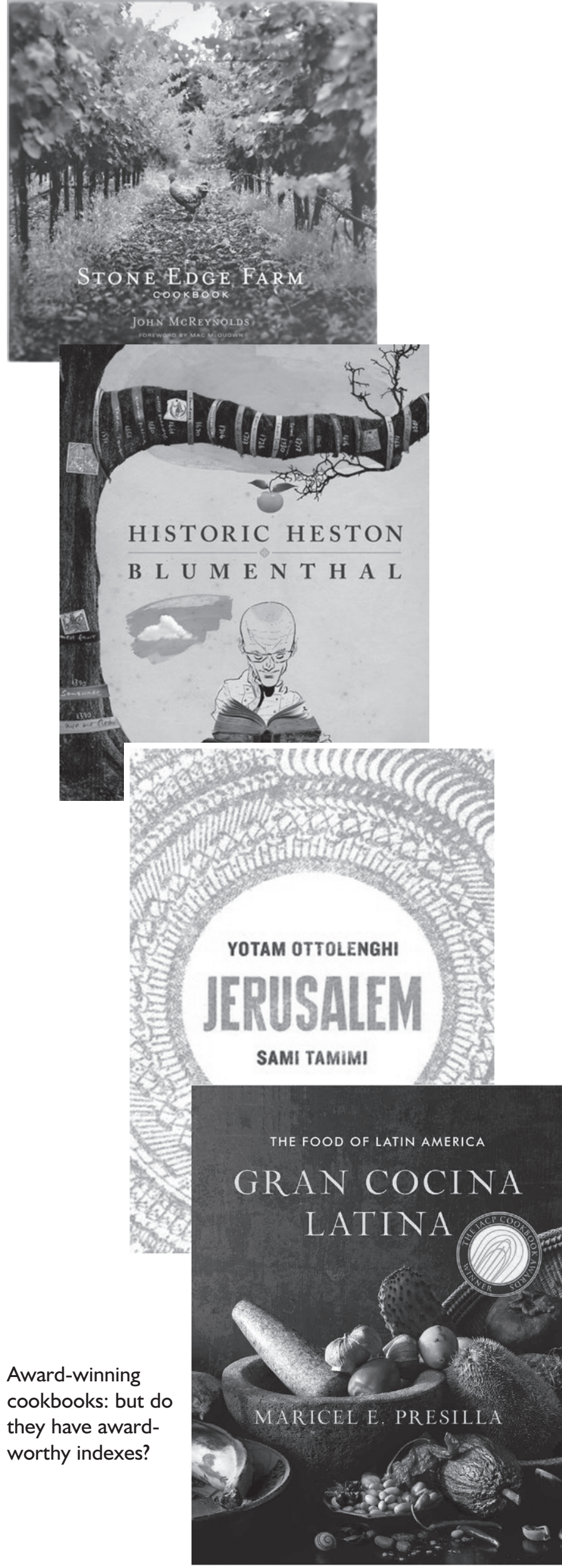


Weir, 2010) include foreign language terms without English language translations.

Several factors must be considered when deciding whether to index foreign language terms and their English language translations (Bertelsen, 2009: 38-9). First, this practice will increase the length of the index. This is a concern if the index has space limitations. Second, the indexer must have sufficient foreign language expertise to know how to transform long phrases into headings and subheadings. Third, Bertelsen argued that an index with italicized foreign language terms 'creates visual confusion.' Nevertheless, including foreign language terms and their English language translations will provide the cookbook user with more access to information.

\section{Design}

The design of each cookbook index in this study is clean and straightforward. None of the indexes is illustrated with photographs or drawings. The indexes with the least amount of white space are found in Couture chocolate (Curley, 2011), Ice creams, sorbets \& gelati (Weir and Weir, 2010), Stone Edge Farm cookbook (McReynolds, 2013), and Tasting India (Manfield, 2011). Of course, this aspect of index design is usually beyond the indexer's control.

\section{Subheadings}

Cookbook indexes usually have subheadings that are indented rather than run-in (Shere, 2014: 3). All of the indexes in this study have indented subheadings.

\section{Subentry arrangement}

Subentries for recipe titles may be listed in an exact quote style or in an inverted style. In the exact quote style, recipe titles are listed exactly as they appear in the text. The following entries illustrating the exact quote style are excerpted from the index in Country cooking of Ireland (Andrews, 2009: 375).

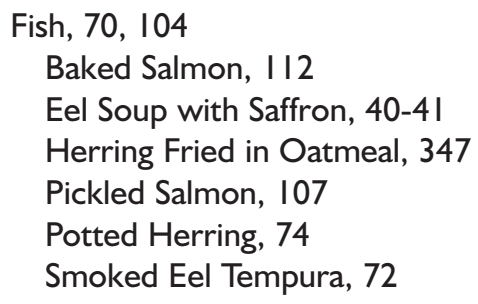

The inverted style of subheadings allows the words in the recipe titles to be rearranged to bring forward key elements (Shere, 2014: 3). If the inverted style had been used with the entries listed above, the excerpt might appear as follows:

Fish, 70, 104

Eel Soup with Saffron, 40-4I

Eel Tempura, Smoked, 72

Herring Fried in Oatmeal, 347

Herring, Potted, 74

Salmon, Baked, II 2

Salmon, Pickled, 107
Watts (2014: C2) wrote that she found the inverted style 'harder to read.' However, Shere (2014: 3) argued, 'It is important to make long subheading columns as easy as possible for readers to scan, and sometimes it's necessary to make sure that similar recipes fall together. So the title's original word order is not always the best choice, and commas and inversions within subheadings may be advisable.'

The subentry arrangement style varies among the indexes in this study. Seven of the indexes use the exact quote style, and seven use the inverted style.

\section{Levels of subentries}

Watts (2014: C2) reported that one level of subentries was preferred by most of her clients. She wrote, 'When a second level of subentries is added, the multiple indents can get very confusing and lead to ridiculously short lines.' Most of the indexes in this study have one level of subentries. The exception is Rose's heavenly cakes (Beranbaum, 2009) which uses two levels of subentries.

\section{Parenthetic word endings}

Parenthetic plurals may be used in main headings designating ingredients or types of dishes (Shere, 2004: 9). Examples of parenthetic plurals include 'almond(s),' 'mango(es)' and 'strawberry(ies)'. It is not necessary to use a parenthetic plural if the terms under a main heading are all singular or all plural. However, if the terms under a main heading include a mix of singular and plural forms, a parenthetic plural main heading is appropriate. Six of the indexes in this study use parenthetic plurals. The index in Around my French table (Greenspan, 2010) also includes the parenthetic word endings of '(d)' and '(ed),' resulting in words such as 'spice(d),' 'butter(ed),' and 'herb(ed)(s).'

\section{Capitalization}

Capitalization may help the reader distinguish between main headings, recipe titles and other entries. The cookbooks in this study vary in their use of capital letters. Four indexes capitalize recipe titles. Three indexes capitalize recipe titles and main headings. One index capitalizes main headings and subheadings. One index capitalizes main headings, recipe titles, and uses all capital letters in names of recipe categories, such as 'SORBETS.'

\section{'Continued' lines}

If the subheadings under a main heading are split between columns or pages, the practice of repeating the heading followed by 'continued' at the top of the next column or page is helpful to the reader (Mulvany, 2005: 212). Only two of the indexes follow this practice for breaks between columns. Two of the indexes follow this practice for breaks between all pages, and five more follow the practice for breaks between a right-hand and a left-hand page. 
Size

Index size may be measured as a ratio of the number of index pages to the number of pages in the book. Mulvany (2005: 72) estimated that a cookbook index would take up 7 to 8 percent of the pages in the book. Hall (2009: 63) required at least 3 percent in her criteria for outstanding indexes. The indexes in this study range from 1.08 percent to 3.39 percent. The largest indexes were found in Brilliant bread (Morton, 2013): 2.7 percent, Around my French table (Greenspan, 2010): 2.76 percent, Rose's heavenly cakes (Beranbaum, 2009): 2.93 percent, Gran cocina Latina (Presilla, 2012): 3.3 percent, and Country cooking of Ireland (Andrews, 2009): 3.39 percent.

\section{Discussion}

This study began with the question 'If a cookbook wins an award for excellence, can we assume that it includes a good index?' The answer to this question is 'usually.' Although one cookbook in the study lacks a proper index, the remaining 14 cookbooks include indexes that provide access to main ingredients, types of dishes and recipe titles. Thirteen of the indexes include cross-references. Ten indexes include bilingual access to foreign language terms.

While all of the indexes use indented subheadings, they vary in other style considerations. Many of these variations may reflect the preferences of the client. Therefore, it is important for the indexer to consult the client about requirements as early as possible in the project (Nickerson, 2009: xi). There may be some room for negotiation in this discussion. Watts (2014: C1) wrote that she suggests changes to her client if she thinks a style could be improved. She noted, 'Sometimes they have gone with a certain approach because no one really thought much about it, perhaps simply carrying on using the style of the first index(es) they had done.'

\section{Conclusion}

'No one who cooks, cooks alone. Even at her most solitary, a cook in the kitchen is surrounded by generations of cooks past, the advice and menus of cooks present, the wisdom of cookbook writers,' wrote Laurie Colwin (2010: ix). The wisdom of culinary indexers also affects the cook in the kitchen. Culinary indexers must be mindful of this responsibility as they strive to provide useful, comprehensive and accurate access to information.

\section{References}

Note: general references are provided here; details of the cookbooks winning awards are in the Appendix.

Bertelsen, C. (1999) 'A piece of cake? Cookbook indexing: basic guidelines and resources.' Key Words 7(1), 1, 6-12.

Bertelsen, C. (2009) 'International affairs: indexing ethnic cookbooks,' in A. Nickerson, F. Leise and T. Hudoba (eds.), Indexing specialties: cookbooks, Medford, N.J.: Information Today in association with ASI.

Child, J. (2005) The way to cook. New York: Knopf.
Colwin, L. (2010) Home cooking: a writer in the kitchen. New York: Vintage.

Guild of Food Writers (2015a) 'About.' www.gfw.co.uk/history. cfm (accessed 1 March 2015).

Guild of Food Writers (2015b) 'Awards.' www.gfw.co.uk/guildof-food-writers-awards.cfm (accessed 1 March 2015).

Guillermopreto, A. (2011) Review of Oaxaca al gusto: an infinite gastronomy, by D. Kennedy. New York Review of Books, 28 April, quoted in 'Indexes reviewed.' The Indexer (2011) 29(3), 140.

Hall, A. (2009) 'The perfect recipe: five cookbooks with impeccable indexes,' in A. Nickerson, F. Leise and T. Hudoba (eds.), Indexing specialties: cookbooks, Medford, N.J.: Information Today in association with ASI.

International Association of Culinary Professionals (2015a) 'About IACP.' www.iacp.com/join/more/about_us (accessed 1 March 2015).

International Association of Culinary Professionals (2015b) 'Cookbook awards: winners.' www.iacp.com/award/more/ cookbook (accessed 1 March 2015).

International Organization for Standardization (1996) ISO 999: information and documentation: guidelines for the content, organization and presentation of indexes, 2nd edn. London: BSI.

James Beard Foundation (2015) 'Foundation history.' www. james beard.org/about/history (accessed 1 March 2015).

Means, J. (2009) Review of Kitchen express: 404 inspired seasonal dishes you can make in 20 minutes or less, by M. Bittman. Amazon.com, quoted in 'Indexes reviewed.' The Indexer (2010) 28(1), 45.

Mulvany, N. C. (2005) Indexing books, 2nd edn. Chicago, Ill.: University of Chicago Press.

Nickerson, A. (2009) 'Introduction,' in A. Nickerson, F. Leise and T. Hudoba (eds.), Indexing specialties: cookbooks, Medford, N.J.: Information Today in association with ASI.

Sassen, C. (2003) 'Culinary indexing practices in The Boston Cooking-School Cook Book and The Fannie Farmer Cook Book, 1896-1996.' Key Words 11(1), 20-2.

Sassen, C. (2009) 'Indexes in classic cookbooks: an analysis of the indexes in The Joy of Cooking, 1931-2006,' in A. Nickerson, F. Leise and T. Hudoba (eds.), Indexing specialties: cookbooks, Medford, N.J.: Information Today in association with ASI.

Shere, T. (2004) Indexing cookbooks. Unpublished paper (39 pp.) Available at https://groups.yahoo.com/neo/groups/culinarysiglistserv/files

Shere, T. (2009) 'What's in a name? Indexing recipe titles,' in A. Nickerson, F. Leise and T. Hudoba (eds.), Indexing specialties: cookbooks, Medford, N.J.: Information Today in association with ASI.

Shere, T. (2014) 'Appendix B: Cookbooks' in ASI Best Practices Committee (eds.), Best practices for indexing. Unpublished proposal.

Sicherman, A. (1998) Review of How to cook everything, by M. Bittman. Star Tribune (Minneapolis), 11 November, quoted in 'Indexes reviewed.' The Indexer (1999) 21(3), 138.

Watts, G. (2014) 'Food for thought: the expanding universe of cookbook indexing.' The Indexer 32(4), C1-C5.

Waverman, L. (2008) Review of Anita Stewart's Canada: the food, the recipes, the stories, by Anita Stewart. Globe and Mail, 26 April, quoted in 'Indexes reviewed.' The Indexer (2008) 26(3), 139.

Weinberg, B. H. (1999) 'Exhaustivity of indexes: books, journals and electronic full text: summary of a workshop presented at the 1999 ASI Annual Conference.' Key Words 7(5), 1, 6-19.

Wellisch, H. H. (1995) 'Cookbook indexing,' pp. 94-7 in Indexing from $A$ to $Z$, 2nd edn. New York: H.W. Wilson.

Whitman, J., and Simon, D. (2000) 'Indexing,' pp. 133-47 in 
Recipes into type: a handbook for cookbook writers and editors. Newton, Mass.: Biscuit Books.

\section{Appendix: Award-winning cookbooks, arranged by award and date}

\section{Guild of Food Writers Cookery Book of the Year, 2010-14}

Morton, J. (2013) Brilliant bread. London: Ebury Press.

Ottolenghi, Y. and Tamimi, S. (2012) Jerusalem. London: Ebury Press.

Curley, W. (2011) Couture chocolate. London: Jacqui Small.

Weir, C. and Weir, R. (2010) Ice creams, sorbets and gelati: the definitive guide. London: Grub Street.

Pagrach-Chandra, G. (2009) Warm bread and honey cake: an inspiring collection of international recipes for the home baker. London: Pavilion.

International Association of Culinary Professionals Cookbook of the Year, 2010-14

McReynolds, J. (2013) Stone Edge Farm cookbook. Sonoma, Calif.: Stone Edge Farm.
Ottolenghi, Y. and Tamimi, S. (2012) Jerusalem. Berkeley, Calif.: Ten Speed Press.

Manfield, C. (2011) Tasting India. London: Conran Octopus.

Greenspan, D. (2010) Around my French table: more than 300 recipes from my home to yours. Boston, Mass.: Houghton Mifflin Harcourt.

Beranbaum, R. L. (2009) Rose's heavenly cakes. Hoboken, N.J: Wiley.

\section{James Beard Awards Cookbook of the Year, 2010-14}

Blumenthal, H. (2013) Historic Heston. London: Bloomsbury.

Presilla, M. E. (2012) Gran cocina Latina: the food of Latin America. New York: Norton.

Myhrvold, N. (2011) Modernist cuisine: the art and science of cooking. Bellevue, Wash.: Cooking Lab.

Kennedy, D. (2010) Oaxaca al gusto: an infinite gastronomy. Austin: University of Texas Press.

Andrews, C. (2009) The country cooking of Ireland. San Francisco, Calif.: Chronicle.

Catherine Sassen is principal catalog librarian at the University of North Texas. Email: Catherine. Sassendunt.edu

\section{Enigma and the indexer}

The release in October 2014 of The Imitation Game (based on the life of Alan Turing) is a reminder of the important part played by indexers, in deciphering the Enigma code at Bletchley Park during the Second World War. The story was briefly told in the April 1975 Indexer:

\section{Breaking German war-time cyphers}

Peter Calvocoressi, who was Deputy Head, and later Head, of the Air Section of a (until recently) secret section of British intelligence which operated at Bletchley Park, Bucks., during the Second World War, in an article in The Sunday Times Weekly Review of 24 November 1974, reveals the great usefulness of a card index in the work of the section. He said that, next to the Enigma machine which cracked the cyphers of secret German wireless traffic, the card index which was built up was the section's most important tool. Cryptography and 'intelligence' owe much more to method and card indexes than the more lurid accounts of such work suggest. A few indexers were constantly at work underlining keywords in every deciphered German message. These keywords (names of people and places, units, weapons, code words, special subjects like oil, and scientific terms) were all put on cards. This Air Index was so important and precious that the cards were regularly photographed and the duplicates stored away in safety elsewhere in case the unit at Bletchley was bombed. He wrote: 'I was perhaps prouder of our index than of anything else that I was ultimately responsible for at Bletchley.... It was superbly planned and organised by a man who seemed to have a cross-index inside his own mind.' The staff responsible for this activity 'could not suppress a tinge of smugness when emissaries came from other organizations to learn how to emulate our system'. Peter Calvocoressi is co-author of Total war, a highly-praised history of the Second World War.

Source: Indexer 9(3), 111 (www. theindexer.org/files/ 09-3/09-3_107.pdf).

Elizabeth Wallis and Cherry Lavell wrote a rather fuller account in their article, 'The index of Enigma messages' in the April 2000 Indexer (22(1), 31-3. www. theindexer. org/files/22-1/22-1_031.pdf). Well worth a read (or re-read)!

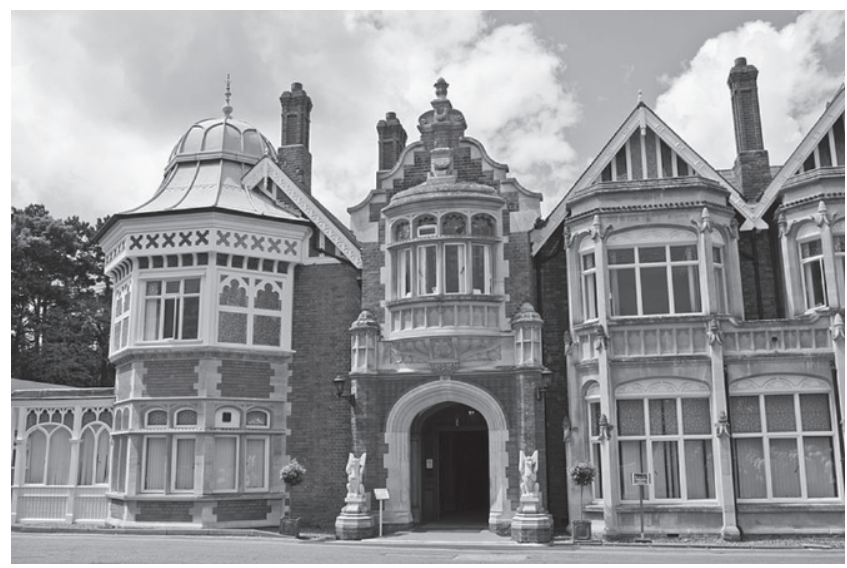

Bletchley Park

picture by Antoine Taveneaux (via Wikimedia Commons) 